\title{
Differential Acclimation of Enzymatic Antioxidant Metabolism and Photosystem II Photochemistry in Tall Fescue under Drought and Heat and the Combined Stresses
}

\author{
Aoyue $\mathrm{Bi}^{1,2}$, Jibiao Fan ${ }^{1,2}$, Zhengrong $\mathrm{Hu}^{1,2}$, Guangyang Wang ${ }^{1,2}$, Erick Amombo ${ }^{1,2}$, \\ Jinmin $\mathrm{Fu}^{1,3 *}$ and $\mathrm{TaO} \mathrm{Hu}^{1,3 *}$ \\ ${ }^{1}$ Wuhan Botanical Garden, Chinese Academy of Sciences, Wuhan, China, ${ }^{2}$ University of Chinese Academy of Sciences, \\ Beijing, China, ${ }^{3}$ China-Africa Center, Chinese Academy of Sciences, Beijing, China
}

\section{OPEN ACCESS}

Edited by:

Richard Sayre,

New Mexico Consortium at Los

Alamos National Labs, USA

Reviewed by:

Vasileios Fotopoulos,

Cyprus University of Technology,

Cyprus

Naser A. Anjum,

University of Aveiro, Portugal Li-Song Chen,

Fujian Agriculture and Forestry

University, China

*Correspondence:

Jinmin Fu

jfu@wbgcas.cn

$\mathrm{TaO} \mathrm{Hu}$

hut420@wbgcas.cn

Specialty section:

This article was submitted to

Plant Physiology

a section of the journal

Frontiers in Plant Science

Received: 11 January 2016

Accepted: 22 March 2016

Published: 14 April 2016

Citation:

Bi A, Fan J, Hu Z, Wang G, Amombo E, Fu J and Hu T (2016) Differential Acclimation of Enzymatic

Antioxidant Metabolism and Photosystem II Photochemistry in Tall Fescue under Drought and Heat and

the Combined Stresses.

Front. Plant Sci. 7:453 do: $10.3389 /$ fpls.2016.00453
Quality inferiority in cool-season turfgrass due to drought, heat, and a combination of both stresses is predicted to be more prevalent in the future. Understanding the various response to heat and drought stress will assist in the selection and breeding of tolerant grass varieties. The objective of this study was to investigate the behavior of antioxidant metabolism and photosystem II (PSII) photochemistry in two tall fescue genotypes (PI 234881 and PI 578718) with various thermotolerance capacities. Wide variations were found between heat-tolerant PI 578718 and heat-sensitive PI 234881 for leaf relative water content, malondialdehyde and electrolyte leakage under drought, high-temperature or a combination of both stresses. The sensitivity of $\mathrm{Pl} 234881$ exposed to combined stresses was associated with lower superoxide dismutase activity and higher $\mathrm{H}_{2} \mathrm{O}_{2}$ accumulation than that in PI 578718. Various antioxidant enzymes displayed positive correlation with chlorophyll content, but negative with membrane injury index at most of the stages in both tall fescue genotypes. The JIP-test analysis in PI 578718 indicated a significant improvement in $A B S / R C, T R_{0} / R C, R E_{0} / R C, R E_{0} / A B S$ values as compared to the control regime, which indicated that PI 578718 had a high potential to protect the PSII system under drought and high temperature stress. And the PS II photochemistry in PI 234881 was damaged significantly compared with PI578718. Moreover, quantitative RT-PCR revealed that heat and drought stresses deduced the gene expression of $p s b B$ and $p s b C$, but induced the expression of $p s b A$. These findings to some extent confirmed that the various adaptations of physiological traits may contribute to breeding in cold-season turfgrass in response to drought, high-temperature, and a combination of both stresses.

\footnotetext{
Keywords: tall fescue, drought stress, heat stress, antioxidant enzymes, chlorophyll a fluorescence (OJIP), gene expression
}

Abbreviations: CAT, Catalase; Chl, Chlorophyll; DW, Dry weight; EL, Electrolyte leakage; FW, Fresh weight; MDA, Malondialdehyde; OEC, Oxygen-evolving complex; POD, Peroxidase; PSI, Photosystem I; PSII, Photosystem II; PQ, Plastoquinone; ROS, Reactive oxygen species; RWC, Relative water content; SOD, Superoxide dismutase. 


\section{INTRODUCTION}

Genetically diverse plant populations display variation response patterns under various abiotic environments (Baxter and Dilkes, 2012). Therefore, a better understanding of differential adaptations to the diverse environment among different plant species with different abiotic tolerant can provide crucial information to improve the crop breeding process. Drought, high temperature and a combination of both stresses are the major abiotic stresses which limit the plant growth (Huang and Gao, 1999), which gives rise to a series of morphological, physiological, biochemical, and molecular changes that adversely influence plant growth and productivity (Wang et al., 2001).

Drought, high-temperature, and a combination of both stresses can cause the changes in turf quality as well as leaf water potential, cell membrane stability, photosynthetic rate, photochemical efficiency, and carbohydrate accumulation (Huang et al., 1998; Huang and Gao, 1999; Jiang and Huang, 2000). It was reported that drought and heat stresses limited $\mathrm{CO}_{2}$ uptake in bean (Phaseolus vulgaris L.) (Yordanov et al., 1997), leaf growth in sorghum [Sorghum bicolor (L.) Moench] (Kaigama, 1982), and leaf water content and potential in wheat (Triticum aestivum L.) (Shah, 1992). These diverse environmental stresses often result in activation of similar cell signaling pathways (Shinozaki and Yamaguchi-Shinozaki, 2000; Knight and Knight, 2001; Zhu, 2001, 2002), and cellular responses, such as the production of stress proteins, up-regulation of anti-oxidants, and accumulation of compatible solutes (Cushman and Bohnert, 2000).

Plants respond to the stress-induced production of reactive oxygen species (ROS) by changing component quantities of their defensive system (Zabalza et al., 2008). As mentioned, above, ROS consist of non-radical $\left(\mathrm{H}_{2} \mathrm{O}_{2}\right)$ and free radical species $\left(\mathrm{O}_{2}^{-\bullet}\right.$, $\mathrm{OH}^{\bullet}, \mathrm{OH}_{2}^{*}$ ). High ROS concentration is potentially detrimental to plants cells. ROS accumulation will have a significant impact to indispensable biomolecules [e.g., DNA, proteins, lipids, chlorophyll (Chl) and membrane] (Blokhina et al., 2003). Higher plants normally protect cells and subcellar systems against the cytotoxic effect by a complex antioxidant non-enzymatic and enzymatic systems (Ali et al., 2008). Enzymatic antioxidants consist of superoxide dismutase (SOD), catalase (CAT), and peroxidase (POD), which can remove $\mathrm{H}_{2} \mathrm{O}_{2}$, neutralize or scavenge free radicals and oxy-intermediates (Karpinski and Muhlenbock, 2007; Lee et al., 2007). Other studies have indicated that young senescing leaf cells excessively produced ROS under stressful conditions, which are eventually removed by complex non-enzymatic compounds (i.e., ascorbate, glutathione, $\alpha$ tocopherol) and enzymes (i.e., CAT, SOD, glutathione POD, and glutathione reductase) (Scandalios et al., 1997). The denominator in all the adverse conditions is the imbalance between prooxidants and antioxidants disruption of homeostasis (Pinheiro et al., 2004). Apart from their detrimental effects on cells, ROS can simultaneously function as signaling molecules in reaction cascades activated by the external and developmental stimuli (Demiral et al., 2011). Therefore, it has been major focus area for further research. However, the specific antioxidant mechanisms involved in abiotic stress tolerance has not been fully elucidated.
Photosystem II (PSII), with its oxygen-evolving complex (OEC), is one of the three main stress-sensitive segments in the photosynthetic machinery (Mohanty et al., 2007; Murata et al., 2007). PSII is the core portion of the photosynthesis process which consists of a multi-subunit complex, and is embedded in the thylakoid membranes of higher plants. PSII catalyzes the dissociation of water into dioxygen and reducing equivalents by solar energy (Umena et al., 2011). The PSII reaction center is composed of a D1-D2 heterodimer, which binds all the essential cofactors for the electron transfer from the water-splitting complex to the plastoquinone (PQ) pool producing excess ROS (Pfannschmidt, 2003; Pospíšil, 2012). PSII is vulnerable to heat stress, which results in serious damage on PSII components (Hideg et al., 2002).

Tall fescue (Festuca arundinacea Schreber) is a windpollinated, self-infertile polyploid ( $2 \mathrm{n}=6 \mathrm{x}=42$ chromosomes $)$ perennial cool-season forage and turf grass. This botanical species is one of the most vital and intensively studied turf species globally (Wang et al., 2004). In the present study, two tall fescue accessions PI 234881 and PI 578718 with different hightemperature tolerance, whose thermotolerance was identified through the summer adaptation test in Wu Han for 2 years, were used to investigate response under high-temperature stress (Hu et al., 2015). The present work was conducted to investigate the variation acclimation of enzymatic antioxidant metabolism and PSII photochemistry in response to drought, heat, and the combined stress for tall fescue genotypes differing in hightemperature tolerance.

\section{MATERIALS AND METHODS}

\section{Plant Materials}

This study was conducted at Wuhan Botanical Garden, Chinese Academy of Science, Wuhan, China in 2014. Two tall fescue accessions PI 234881 and PI 578718 were seeded in plastic pots $(13 \mathrm{~cm}$ in diameter and $15 \mathrm{~cm}$ deep) with nutrient soil. Seedlings were grown for 7 days under controlled conditions (light/dark regime of $14 / 10 \mathrm{~h}$ at $22 / 18^{\circ} \mathrm{C}$, relative humidity of $70 \%$, photosynthetic photon flux density of (PAR) 360 $\mu$ mol. $\left.\mathrm{m}^{-2} \cdot \mathrm{s}^{-1}\right)$ and were sub-irrigated every other day with a half-strength Hoagland's solution (Hoagland and Arnon, 1950).

\section{Stress Treatments}

After 7-day of pre-adaptation, tall fescue with similar growth rate was arranged in a randomized complete block design with four replicates. The experiment included two temperatures and two soil moisture regimes. Temperature treatments were optimum $\left(22^{\circ} \mathrm{C} / 18^{\circ} \mathrm{C}\right.$, day/night) and high $\left(35^{\circ} \mathrm{C} / 30^{\circ} \mathrm{C}\right)$. Soil moisture treatments were (i) well-watered, i.e., irrigating every day until there was free drainage at bottom of the pots (ii) drought stress, i.e., withholding irrigation at optimum temperature. The treatments were defined as follows: (i) control: optimum soil moisture and temperature; (ii) drought: low soil moisture and optimum temperature (for 7-day stress until the soil moisture was lower than 30\%); (iii) heat: optimum soil moisture and high temperature (for 6-day normal control and 1-day high temperature); (iv) drought + heat: low soil moisture and high temperature. Soil moisture was monitored with time domain 
reflectometry (TDR, Soil moisture Equipment Corp., CA; for 6-day drought stress and 1-day drought and high temperature stress). All groups were harvested on the 14th day. Fully expanded 3rd leaves of tall fescue were collected and stored at $-80^{\circ} \mathrm{C}$ for subsequent analysis.

\section{Measurements}

\section{Chlorophyll a Fluorescence Transient}

Fully expanded 3rd leaves (from bottom) were used for fluorescence measurements. All measurements were conducted by a pulse-amplitude modulation (PAM) fluorometer (PAM 2500, Heinz Walz GmbH) with high time resolution $(10 \mu \mathrm{s})$. The leaves were stored under dark conditions for $30 \mathrm{~min}$ using leaf clips and then saturating light intensity was set to $2000 \mu \mathrm{mol}$ photons $\mathrm{m}^{-2} \mathrm{~s}^{-1}$ (sufficient excitation intensity to insure closure of all PSII reaction centers to obtain a true fluorescence intensity of FM). The leaves were exposed to the strong light for $5 \mathrm{~s}$ (Korres et al., 2003). Finally fluorescence curves extending from minimal fluorescence (Fo) to maximal fluorescence (Fm) were produced by the OJIP transient. For each group, measurements were repeated at least four times. The PSII parameters and OJIP transient were analyzed according to Strasser et al. (2004).

\section{The JIP-Test}

The fluorescence intensity emitted by plants changed over time. When the tall fescue was exposed to light from the dark adaption, fluorescence intensity increased and then declined. Chlorophyll fluorescence kinetics curve referred to the changing processfrom point $\mathrm{O}$ to point $\mathrm{P}$ and a typical JIP-test included four phrase: O-J (0.05 5 ms), J-I (5 50 ms), and I-P (50 1000 ms) which is based on the energy fluxes in biofilm. This provided a convenient tool for the further investigation of photosynthesis. The energy flow begins by the absorption (ABS) of light by PSII antenna pigments and ends with the reduction of the end electron acceptors (RE) at the Photosystem I (PSI) electron acceptor side driven by PSI (Stirbet, 2011). Detailed information of the introduced parameters is listed in Table $\mathbf{1 .}$

\section{Leaf Relative Water Content}

After the stress treatments, fully expanded 3rd leaves of tall fescue were collected to determine the fresh weight (FW). The leaves were then stored in demonized water for $12 \mathrm{~h}$ under room temperature. Subsequently, turgid weights (TW) were determined, and then the leaves were put in oven at $80^{\circ} \mathrm{C}$ for 3 days. The dry weight (DW) was measured and followed by calculation of relative water content (RWC) using this formula:

$$
R W(\%)=\frac{F W-D W}{T W-D W} \times 100
$$

\section{Chlorophyll Content}

To determine the leaf $\mathrm{Chl}$ content, we employed the method described by Hiscox and Israelstam (1979). Fresh leaves (0.1 g) were sheared and soaked in a tube. A $10 \mathrm{~mL}$ dimethylsulfoxide was added and the contents were kept in darkness for 72 h. Finally, the absorbance of samples at 645 and $663 \mathrm{~nm}$ was measured with spectrophotometer (UV-2600, UNICO, Shanghai).

\section{Lipid Peroxidation}

Lipid peroxidation was measured in terms of MDA content described by Heath and Packer (1968). One ml of supernatant was added in $4 \mathrm{ml}$ of $20 \%(\mathrm{v} / \mathrm{v})$ trichloroacetic acid containing $0.5 \%(\mathrm{v} / \mathrm{v})$ thiobarbituric acid. The mixture was incubated at $95^{\circ} \mathrm{C}$ for $30 \mathrm{~min}$ in a water bath and cooled quickly in an ice bath. The aliquots were centrifuged at $10,000 \times \mathrm{g}$ for $10 \mathrm{~min}$ and absorbance of the supernatant was read at 532 $\mathrm{nm}$. The value for the non-specific absorption at $600 \mathrm{~nm}$ was subtracted from the $532 \mathrm{~nm}$ reading. Blank contained complete reaction mixture without enzyme solution. The concentration of MDA was calculated by MDA's extinction coefficient of 155 $\mathrm{mM}^{-1} \mathrm{~cm}^{-1}$.

\section{Electrolyte Leakage}

To determine electrolyte leakage (EL), about $0.1 \mathrm{~g}$ of random sampling leaves were washed with deionized water three times and cut into $0.5 \mathrm{~cm}$ long fragments. The test tubes were filled with $15 \mathrm{ml}$ deionized water and shaken for $24 \mathrm{~h}$ at $25^{\circ} \mathrm{C}$. The initial conductivity $(\mathrm{Ci})$ was measured using a conductivity meter (JENCO-3173, Jenco Instruments, Inc., San Diego, CA, USA). The test tubes were autoclaved at $121^{\circ} \mathrm{C}$ for $30 \mathrm{~min}$ to completely disrupt the tissues and release all electrolytes. The conductivity of the incubation solution with killed tissues (Cmax) was determined after the solution had cooled down to room temperature. The relative EL was calculated using the formula: $\mathrm{EL}(\%)=(\mathrm{Ci} / \mathrm{Cmax}) \times 100$.

\section{Enzyme Activity}

For enzyme extracts and assays, The contents were homogenized with $4 \mathrm{ml}$ phosphate buffer $(50 \mathrm{mM}, \mathrm{pH} 7.8)$ which contained $0.7 \% \mathrm{NaH}_{2} \mathrm{PO}_{4} \cdot 2 \mathrm{H}_{2} \mathrm{O}$ and $1.64 \% \mathrm{Na}_{2} \mathrm{HPO}_{4} \cdot 12 \mathrm{H}_{2} \mathrm{O}$. Enzyme extractions were performed at $4{ }^{\circ} \mathrm{C}$. The homogenate was centrifuged at $15,000 \times \mathrm{g}$ for $30 \mathrm{~min}$ and supernatant was collected.

Soluble protein content was measured according to the method described by Bradford (1976). Briefly, $3 \mathrm{ml}$ of Bradford solution containing $0.01 \%$ Commassie Blue G250 (w/v), 4.7\% ethanol $(\mathrm{v} / \mathrm{v})$, and $8.5 \%$ phosphoric acid $(\mathrm{v} / \mathrm{v})$ were mixed with $30 \mu \mathrm{l}$ of supernatant. The absorption of the mixture was determined at $595 \mathrm{~nm}$ using a spectrophotometer (UV-2600, UNICO Instruments Co., Ltd., Shanghai, China). Soluble protein content was calculated by the formula obtained by bovine serum albumin standard curve.

The SOD activity was measured as described previously (Giannopolitis and Ries, 1977). The assays were performed at $25^{\circ} \mathrm{C}$ and the $3 \mathrm{~mL}$ reaction mixture consisted of $50 \mathrm{mM}$ phosphate buffer solution (PBS; pH 7.8), $60 \mathrm{mM}$ Riboflavin, 195 $\mathrm{mM}$ Met, $3 \mathrm{mM}$ EDTA, $1.125 \mathrm{mM}$ NBT and $0.1 \mathrm{~mL}$ enzyme extract. The tested samples were incubated for 10-30 min under 13000 lux irradiance. The absorbance at $560 \mathrm{~nm}$ was recorded. One unit of enzyme activity was determined as the amount of the enzyme to reach an inhibition of 50\% NBT reduction rate.

Peroxidase activity was determined based on the guaiacol oxidation using $\mathrm{H}_{2} \mathrm{O}_{2}$ (Chance and Maehly, 1955). The reaction mixture consisted of $100 \mathrm{mM}$ sodium-acetic buffer $(\mathrm{pH} 5.0), 0.25 \%(\mathrm{w} / \mathrm{v})$ guaiacol and $0.75 \% \mathrm{H}_{2} \mathrm{O}_{2}$. Prior 
TABLE 1 | Photosynthetic parameters deduced by the JIP-test analysis of fluorescence transients.

\begin{tabular}{|c|c|c|c|c|c|c|c|c|}
\hline \multicolumn{2}{|c|}{ C } & \multicolumn{2}{|c|}{ D } & \multicolumn{2}{|c|}{$\mathbf{H}$} & \multicolumn{2}{|c|}{$H+D$} & \multirow[t]{2}{*}{ Definitions } \\
\hline PI234881 & PI578718 & PI234881 & PI578718 & PI234881 & PI578718 & PI234881 & PI578718 & \\
\hline
\end{tabular}

\section{DATA EXTRACTED FROM THE RECORDED OJIP FLUORESCENCE TRANSIENT CURVES}

\begin{tabular}{|c|c|c|c|c|c|c|c|c|c|}
\hline$F_{0}=F_{20 \mu s}$ & $0.54 b$ & $0.28 a$ & $0.68 a$ & $0.27 a$ & $0.57 b$ & $0.27 a$ & $0.67 a$ & $0.29 a$ & $\begin{array}{l}\text { Fluorescence at time } t \text { after onset of actinic } \\
\text { illumination }\end{array}$ \\
\hline$F_{\mathrm{K}}$ & $1.17 \mathrm{~b}$ & $0.63 a b$ & $1.32 \mathrm{a}$ & $0.65 a$ & $1.2953 a$ & $0.60 c$ & $1.33 a$ & $0.61 b c$ & Fluorescence value at $300 \mu \mathrm{s}$ \\
\hline$F_{\jmath}$ & $1.26 \mathrm{~b}$ & $0.74 a$ & $1.39 a$ & $0.75 a$ & $1.405 a$ & $0.68 b$ & $1.41 \mathrm{a}$ & $0.69 b$ & Fluorescence value at the J-step (2 ms) of OJIP \\
\hline$F_{1}$ & $1.73 a$ & $1 \mathrm{a}$ & $1.69 \mathrm{a}$ & $1.02 \mathrm{a}$ & $1.79 \mathrm{a}$ & $0.89 b$ & $1.68 \mathrm{a}$ & $0.88 b$ & Fluorescence value at the I-step (30 ms) of OJIP \\
\hline$F_{P} \equiv F_{M}$ & $2.16 \mathrm{a}$ & $1.16 \mathrm{a}$ & $2.06 \mathrm{a}$ & $1.15 \mathrm{a}$ & $2.07 a$ & $1.06 \mathrm{~b}$ & $2.02 a$ & $1.04 b$ & Fluorescence value at the peak of OJIP test \\
\hline$M_{0}$ & $1.57 \mathrm{~b}$ & $1.59 b$ & $1.86 \mathrm{a}$ & $1.72 \mathrm{a}$ & $1.93 a$ & $1.65 a b$ & $1.91 \mathrm{a}$ & $1.72 \mathrm{a}$ & $\begin{array}{l}\text { Approximate value of the initial slope of } \\
\text { fluorescence transient curves }\end{array}$ \\
\hline
\end{tabular}

\begin{tabular}{|c|c|c|c|c|c|c|c|c|c|}
\hline \multicolumn{10}{|c|}{ SPECIFIC ENERGY FLUXES (PER ACTIVE PSII REACTION CENTER) } \\
\hline ABS/RC & $4.69 b$ & $4.01 b$ & $5.49 a$ & $4.08 \mathrm{~b}$ & $4.81 b$ & $4.25 a b$ & $5.48 \mathrm{a}$ & $4.48 \mathrm{a}$ & Absorbed photon flux per RC \\
\hline $\mathrm{TR}_{0} / \mathrm{RC}$ & $3.50 a$ & $3.04 \mathrm{~b}$ & $3.63 a$ & $3.13 a b$ & $3.48 a$ & 3.17ab & $3.57 a$ & $3.2 \mathrm{a}$ & $\begin{array}{l}\text { Trapped excitation flux (leading to QA reduction) } \\
\text { per } \mathrm{RC}\end{array}$ \\
\hline $\mathrm{ET}_{0} / \mathrm{RC}$ & $1.94 a$ & $1.45 a$ & $1.77 \mathrm{~b}$ & $1.41 \mathrm{a}$ & $1.54 \mathrm{c}$ & $1.53 a$ & $1.66 \mathrm{bc}$ & $1.48 \mathrm{a}$ & Electron transport flux (further than QA-) per $\mathrm{RC}$ \\
\hline $\mathrm{RE}_{0} / \mathrm{RC}$ & $0.93 a$ & $0.57 b$ & $1.04 a$ & $0.48 c$ & $0.65 b$ & $0.7 a$ & $0.93 a$ & $0.69 a$ & $\begin{array}{l}\text { Electron flux reducing end electron acceptors at } \\
\text { the PSI acceptor side, per RC }\end{array}$ \\
\hline
\end{tabular}

\begin{tabular}{|c|c|c|c|c|c|c|c|c|c|}
\hline \multicolumn{10}{|c|}{ QUANTUM YIELDS AND EFFICIENCIES/PROBABILITIES } \\
\hline $\begin{array}{l}\varphi \mathrm{PO} \equiv \\
\mathrm{TR}_{0} / \mathrm{ABS}\end{array}$ & $0.75 a$ & $0.76 a$ & $0.66 b$ & $0.77 a$ & $0.72 \mathrm{a}$ & $0.75 a b$ & $0.65 b$ & $0.72 b$ & $\begin{array}{l}\text { Maximum quantum yield for primary } \\
\text { photochemistry, namely } F_{V} / F_{M}\end{array}$ \\
\hline $\begin{array}{l}\psi_{\mathrm{EO}_{0}} \equiv \\
\mathrm{ET}_{0} / \mathrm{TR}_{0}\end{array}$ & $0.55 a$ & $0.48 a$ & $0.49 b$ & $0.45 a$ & $0.44 c$ & $0.48 a$ & $0.46 b c$ & $0.46 a$ & $\begin{array}{l}\text { Efficiency/probability with which a PSIl trapped } \\
\text { electron is transferred from } Q_{A} \text { to } Q_{B}\end{array}$ \\
\hline $\begin{array}{l}\varphi \mathrm{EO} \equiv \\
E T_{0} / \mathrm{ABS}\end{array}$ & $0.41 \mathrm{a}$ & $0.36 a$ & $0.33 b$ & $0.35 a b$ & $0.32 b$ & $0.36 a b$ & $0.3 b$ & $0.33 b$ & $\begin{array}{l}\text { Quantum yield of the electron transport flux from } \\
Q_{A} \text { to } Q_{B}\end{array}$ \\
\hline $\begin{array}{l}\delta_{\mathrm{RO}} \equiv \\
\mathrm{RE}_{0} / \mathrm{ET}_{0}\end{array}$ & $0.48 b$ & $0.39 b$ & $0.59 a$ & $0.34 \mathrm{c}$ & $0.42 b$ & $0.46 a$ & $0.56 a$ & $0.47 a$ & $\begin{array}{l}\text { Efficiency/probability with which an electron from } \\
\mathrm{Q}_{\mathrm{B}} \text { is transferred until PSI acceptors }\end{array}$ \\
\hline $\begin{array}{l}\varphi \mathrm{RO} \equiv \\
\mathrm{RE}_{0} / \mathrm{ABS}\end{array}$ & $0.2 \mathrm{a}$ & $0.14 b$ & $0.19 a$ & $0.12 \mathrm{c}$ & $0.136 c$ & $0.16 a b$ & $0.17 b$ & $0.17 a$ & $\begin{array}{l}\text { Quantum yield for reduction of end electron } \\
\text { acceptors at the PSI acceptor side }\end{array}$ \\
\hline$\gamma_{\mathrm{RC}}$ & $0.18 \mathrm{a}$ & $0.2 \mathrm{a}$ & $0.15 b$ & $0.19 a$ & $0.17 a$ & $0.19 a b$ & $0.15 b$ & $0.18 b$ & $\begin{array}{l}\text { Probability that a PSII Chl molecule functions as } \\
\text { RC }\end{array}$ \\
\hline $\mathrm{RC} / \mathrm{ABS}$ & $0.21 \mathrm{a}$ & $0.25 a$ & $0.18 b$ & $0.25 a b$ & $0.20 \mathrm{a}$ & $0.24 a b$ & $0.18 b$ & $0.23 b$ & Number of $Q_{A}$ reducing $R C$ s per PSIl antenna Chl \\
\hline \multicolumn{10}{|c|}{ PERFORMANCE INDEXES (PI, COMBINATION OF PARAMETERS) } \\
\hline $\mathrm{PI}_{\mathrm{ABS}}$ & $0.79 a$ & $0.73 a$ & $0.36 \mathrm{~b}$ & $0.67 a b$ & $0.44 b$ & $0.66 \mathrm{ab}$ & $0.30 b$ & $0.52 b$ & $\begin{array}{l}\mathrm{PI} \text { (potential) for energy conservation from exciton } \\
\text { to the reduction of intersystem electron }\end{array}$ \\
\hline $\mathrm{Pl}_{\text {total }}$ & $0.72 a$ & $0.48 a$ & $0.50 b$ & $0.35 b$ & $0.33 c$ & $0.56 a$ & $0.38 \mathrm{c}$ & $0.44 a b$ & $\begin{array}{l}\text { PI (potential) for energy conservation from exciton } \\
\text { to the reduction of PSI end acceptors }\end{array}$ \\
\hline
\end{tabular}

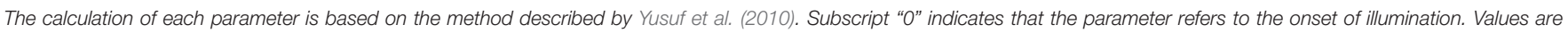
given as the average of 4 replicates, and different letters indicate statistical difference significance at $P<0.05$ among the treatments by Duncan's multiple range tests.

to the absorbance measurement at $460 \mathrm{~nm}$, the reaction mixture was fully dissolved and shaken up. One unit POD activity was defined as the absorbance change of one unit per minute.

The CAT activity was determined by measuring the decrease in absorbance at $240 \mathrm{~nm}$ for $1 \mathrm{~min}$ along with the decomposition of $\mathrm{H}_{2} \mathrm{O}_{2}$ (Chance and Maehly, 1955). The reaction mixture consisted of $50 \mathrm{mM}$ phosphate buffer ( $\mathrm{pH}$ 7.4) and 45 $\mathrm{mM} \mathrm{H}_{2} \mathrm{O}_{2}$ and $0.1 \mathrm{~mL}$ enzyme extract. One unit CAT activity was defined as the absorbance change of 0.01 units per minute.

\section{Determination of $\mathrm{H}_{2} \mathrm{O}_{2}$ Content}

Quantification of $\mathrm{H}_{2} \mathrm{O}_{2}$ content was determined using the method of Jena and Choudhuri (1981). One millilitre of supernatant was blended in $1 \mathrm{ml}$ of $0.1 \%$ titanium sulfate containing $20 \% \mathrm{H}_{2} \mathrm{SO}_{4}(\mathrm{v} / \mathrm{v})$ and then centrifuged for $15 \mathrm{~min}$ at $6000 \times \mathrm{g}$. The $\mathrm{A}_{410}$ was immediately determined and compared with a standard curve obtained from known concentrations of $\mathrm{H}_{2} \mathrm{O}_{2}$ and calculated using the extinction coefficient of 0.28 $\mu \mathrm{mol}^{-1} \mathrm{~cm}^{-1}$.

\section{Quantitative RT-PCR Analysis}

For gene expression determination, the samples were first stored at $-20{ }^{\circ} \mathrm{C}$ prepared to the RNA isolation and gene expression analysis. Total RNA was isolated from about $0.1 \mathrm{~g}$ crushed leaves using Trizol-reagent (Invitrogen, Carlsbad, CA) according to instructions.

The first strand cDNA was synthesized from $2 \mu \mathrm{g}$ of total RNA with oligo $(\mathrm{dT})_{12-18}$ primer using cDNA synthesis 
kit (Fermentas, Canada) according to the manufacturer's instructions. The gene-specific primers used for real-time quantitative RT-PCR are listed in Table S1. The housekeeping gene, eEF1A(s), was used as control. SYBR Green I (SigmaAldrich, US) was used to produce a fluorogenic intercalating dye on a Chromo4 Real-Time Detection System (MJ Research, Cambridge, MA). The quantitative RT-PCR progress for the amplifications was $94^{\circ} \mathrm{C}, 3 \mathrm{~min}$, followed by 38 cycles of $95^{\circ} \mathrm{C}$ for $10 \mathrm{~s}, 20 \mathrm{~s}$ annealing for different primer at $50-55^{\circ} \mathrm{C}$, and $72^{\circ} \mathrm{C}$ for $20 \mathrm{~s}$, with a final elongation at $72^{\circ} \mathrm{C}$ for $5 \mathrm{~min} .38$ cycles, followed by extension at $72^{\circ} \mathrm{C}$ for $5 \mathrm{~min}$. The PCR products were further operated in a $1.2 \%$ agarose gel in $1 \times \mathrm{TAE}$ and stained with $\mathrm{EtBr}$, and the band intensity was quantified using imaging software (Tanon 2500, Tanon Science and Technology Co., Ltd., Shanghai, China).

\section{Statistical Analysis}

In the experiments, all results were expressed as mean $\pm S E$ (standard error) of four replicates. The data were subjected to analysis of variance (ANOVA) using the SPSS statistical software package (Ver.16.0, SPSS Inc., Chicago, IL, USA) and DPS v7.05. The graphs were produced using Origin 8.0 (Origin Lab Inc., Hampton, USA) and Adobe Photoshop (Adobe Inc., San Jose, USA). For RT-qPCR, the DDCq method was used to determine the changes of target gene expression based on normalization with the reference gene. Different letters in tables and histograms indicate significant differences between treatments $(P<0.05)$ based on LSD test.

\section{RESULTS}

\section{Leaf Relative Water Content}

When plants were exposed to drought, heat and combination of the two stresses, the RWC in PI 234881 was decreased compared to the control (Table 2). The RWC was reduced by $35.99,6.47$, and $16.1 \%$ under drought, heat and a combination of the two stresses, respectively. On the other hand, PI 578718 experienced RWC reduction by $4.4 \%$ under drought stress. Under a combination of the two stresses, there was a $7.5 \%$ significant RWC decrease in heat tolerant PI 578718, which was greater than in heat sensitive PI 234881.

\section{Chlorophyll Content}

Under drought, heat and a combination of the two stresses, the leaf Chl content in PI 234881 decreased compared to the control (Table 2). This decrease was $33.3 \%$ in drought, $12.24 \%$ in heat and $33.52 \%$ in their combination. Notably, the Chl content was significantly affected in PI 578718 by all stress groups. However, the combination stress caused a more severe reduction by $30.31 \%$ in Chl content than either stress alone.

\section{Lipid Peroxidation}

In the heat sensitive genotype PI 234881, the effect of the combined stress was similar to that of heat stress, while drought stress enhanced the MDA content by $44.91 \%$ (Figure 1A). However, in PI 578718 lipid peroxidation was more pronounced under the combined stresses than either stress alone. The combined stresses enhanced the MDA content of PI 578718 by $74.1 \%$.

\section{Electrolyte Leakage}

Drought and the combination stresses caused a significant increase in EL in the leaves of the when compared to the control plants (Figure 1B). Under drought and combination stresses conditions, the increase in EL was 22.26 and $57.4 \%$ greater in PI 578718 , respectively.

\section{Antioxidant Enzyme Activities}

Generally, the tall fescue under drought, heat and the combination of the two stresses displayed different patterns of the SOD, CAT, and POD activities, when compared to the controls (Figures 2A-C).

The SOD activity in PI 234881 was decreased by 58, 66.4, and $70.95 \%$ under drought, heat, and the combination of the two stresses, respectively (Figure 2A). In the heat-tolerant genotype PI 578718, no significant difference in SOD activity was observed between the stress and control regime. However, the SOD activity increased by $15.37 \%$ under combined stress as compared with the control, but decreased by 18.92 and $12.35 \%$ under drought and heat stress, respectively. The constitutive level of POD in PI 578718 (heat tolerant) was higher than in PI 234881 under controlled conditions (Figure 2B). The POD activity in PI 234881 was increased by 21.33 and $53.12 \%$ under heat and the combined stress respectively. On one hand, drought stress in PI 234881 dramatically enhanced the POD activity by $92.61 \%$. There

TABLE 2 | Effects of stress treatments on RWC and Chl content of heat sensitive PI 234881 and heat tolerant PI 578718 under control (C), drought (D), heat $(\mathrm{H})$, combined stress $(\mathrm{DH})$.

\begin{tabular}{|c|c|c|c|c|}
\hline & C & D & $\mathbf{H}$ & DH \\
\hline \multicolumn{5}{|c|}{$--\mathrm{PI} 234881--$} \\
\hline RWC(\%) & $98.42 \pm 1.86 a$ & $63 \pm 5.63 c$ & $92.05 \pm 2.03 a b$ & $82.57 \pm 1.91 b$ \\
\hline $\mathrm{Chl}\left(\mathrm{mg} \mathrm{g}^{-1} \mathrm{FW}\right)$ & $35.78 \pm 0.282 a$ & $23.87 \pm 3.11 b$ & $31.4 \pm 1.32 \mathrm{ab}$ & $23.79 \pm 3.67 b$ \\
\hline \multicolumn{5}{|c|}{ - - PI 578718- - } \\
\hline RWC(\%) & $99.39 \pm 1.5 a$ & $95.02 \pm 0.81 b c$ & $96.3 \pm 1.19 a b$ & $91.94 \pm 1.81 \mathrm{c}$ \\
\hline Chl mg g $\left.{ }^{-1} \mathrm{FW}\right)$ & $42.33 \pm 0.328 a$ & $33.67 \pm 4.04 b$ & $31.77 \pm 1.02 \mathrm{~b}$ & $29.5 \pm 2.25 b$ \\
\hline
\end{tabular}

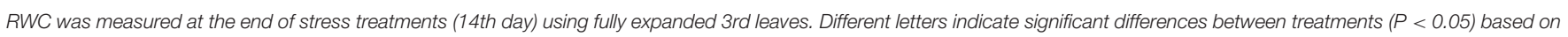
LSD test. 


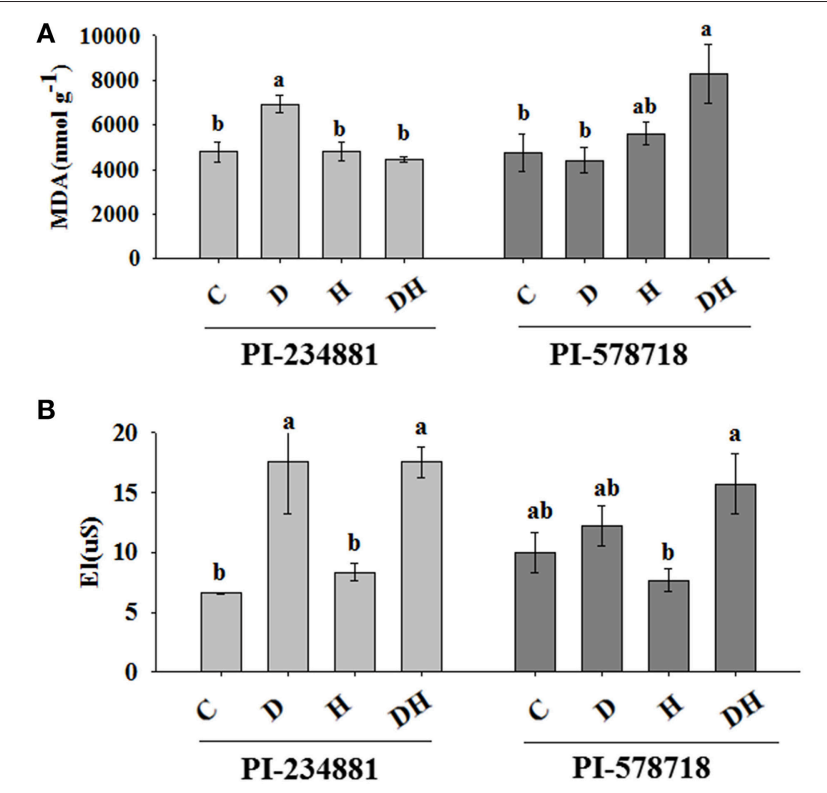

FIGURE 1 | The effects of stress treatments on MDA content (A) and El level (B) in 7th leaves of PI 234881 and PI 578718 under control (C), drought $(D)$, heat $(H)$, combined stress $(\mathrm{DH})$. Different letters indicate significant differences between treatments $(P<0.05)$ based on LSD test.

was no notable changes between stress and control group in the tolerant genotype PI 578718. However, the POD activity under the combined stress was enhanced by $3.28 \%$ as compared to the control groups. On the other hand, the highest POD activity for the all stress conditions was observed in PI 578718. Drought stress enhanced CAT activity by $48.49 \%$ in the PI 234881 while heat stress did not cause any significant change as compared to the control group (Figure 2C). Unexpectedly, combination of stresses decreased CAT activity by $57.45 \%$ in PI 234881. In PI 578718, drought and heat stress increased CAT activity by 2.65-folds and 2.47-folds similarly, combined stress significantly enhanced the CAT activity by 3.36 -folds as compared to the control group in PI 578718.

\section{$\mathrm{H}_{2} \mathrm{O}_{2}$ Level}

Similar to the CAT activity, the $\mathrm{H}_{2} \mathrm{O}_{2}$ content in control regime was higher in PI 234881 compared with PI 578718 (Figure 2D). The $\mathrm{H}_{2} \mathrm{O}_{2}$ content was enhanced in PI 234881 by 64.67 and $2.17 \%$ under drought and heat stress, respectively. Conversely, the combined stress decreased the $\mathrm{H}_{2} \mathrm{O}_{2}$ content of PI 234881 by $24.7 \%$. The stress groups had no effects on $\mathrm{H}_{2} \mathrm{O}_{2}$ content in the tolerant genotype PI 578718.

\section{OJIP Fluorescence Transient and Parameter Analysis}

Drought, heat, and combination stress treatment significantly affected the OJIP fluorescence transient of tall fescue leaves (Figures 3A,B). The OJIP transient of tall fescue leaves in PI 234881 declined dramatically after dark adaption under drought and heat stresses. The Fm reached its minimum after 7 days drought and heat stress treatment, but the value of $F_{0}$ was significantly enhanced compared to other treatments. In the PI
234881 the relative variable fluorescence value receded by $4.76 \%$ under heat stress, but there was no significant difference between drought stress and combination stress $(P>0.05)$. However, in PI 578718 the relative variable fluorescence value was enhanced by 12.82 and $13.68 \%$ under heat and the combination stresses, respectively. Comparing the OJIP transient curves of the two tall fescue accessions we uncovered some unique properties. More notably, the overall trend of fluorescence value in PI 234881 was higher than PI 578718. The values from $F_{0}$ to $F_{k}$ are approximated to control treatment in PI 578718.

The value of fluorescence parameters listed in Table 1 was analyzed by the JIP-test to determine the structural and functional parameters quantifying the photosynthetic behavior of the tall fescue leaves. There were significant differences in the functional parameters between control and treatment regimes. In PI 578718, treatment with combination stress in the leaves significantly enhanced the $\mathrm{ABS} / \mathrm{RC}, \mathrm{TR}_{0} / \mathrm{RC}, \mathrm{RE}_{0} / \mathrm{RC}, \varphi_{\mathrm{R} 0} \equiv$ $\mathrm{RE}_{0} / \mathrm{ABS}$ values as compared with the control group (at $P<$ 0.05). The group treated with drought and heat also significantly reduced the TR0/ABS, $\mathrm{ET}_{0} / \mathrm{ABS}$, and $\mathrm{PI}_{\mathrm{ABS}}$ values at significant level of $P<0.05$. There were no differences in $\mathrm{ET}_{0} / \mathrm{RC}, \mathrm{ET}_{0} / \mathrm{TR}_{0}$ of tall fescue leaves between control and stress groups. The treatment with drought stress significantly declined the $\mathrm{PI}_{\text {total }}$ value, which is a crucial index describing the overall activity of PSII. In PI 234881, the stress treatments significantly reduced the $\mathrm{ET}_{0} / \mathrm{RC}, \varphi_{\mathrm{P} 0} \equiv \mathrm{TR}_{0} / \mathrm{ABS}, \psi_{\mathrm{E} 0} \equiv \mathrm{ET}_{0} / \mathrm{TR}_{0}, \varphi_{\mathrm{E} 0} \equiv \mathrm{ET}_{0} / \mathrm{ABS}$, $\varphi_{\mathrm{R} 0} \equiv \mathrm{RE}_{0} / \mathrm{ABS}$, and $\mathrm{RC} / \mathrm{ABS}$ values. More remarkably, the value of $\mathrm{PI}_{\mathrm{ABS}}$ decreased by $62.03 \%$ under drought and heat stress compared to the control group.

\section{Related Gene Expression about Photosynthetic System}

Heat stress significantly enhanced the gene transcription level of PsbA (protein subunits of PSII core reaction center complex) subunits relative to the control group in PI 234881 (Figure 4). The correlation among gene expression and chlorophyll a fluorescence transient was found in leaves of tall fescue. Similarly, drought and combined stresses increased the gene transcription level of $P s b A$. However there were no difference in gene transcription level of $P s b A$ in PI 578718. The transcription levels under heat stress were higher than those under drought and combined stresses, respectively. Markedly, in the gene transcription level of $P s b B$, stress groups in PI 234881 caused no significant differences compared to the control regime. The gene transcription level of $P s b B$ in PI 578718 was more pronouncedly lower under drought, heat and combined stresses than the control and PsbC in PI 234881. Notably, in the tolerant genotype PI 578718 the combined stress caused a more severe reduction in the gene transcription level of $P s b C$ than either stress alone. The PI 578718 showed less reduction in the gene transcription level of $P s b C$ under drought stress. Generally, the gene transcription level was higher under stress conditions in PI 234881 than in PI 578718.

\section{Associations between Physiological Index and OJIP Kinetic Parameters}

There was a significant correlation among the physiological index and OJIP kinetic parameter (Table 3). A significant positive 


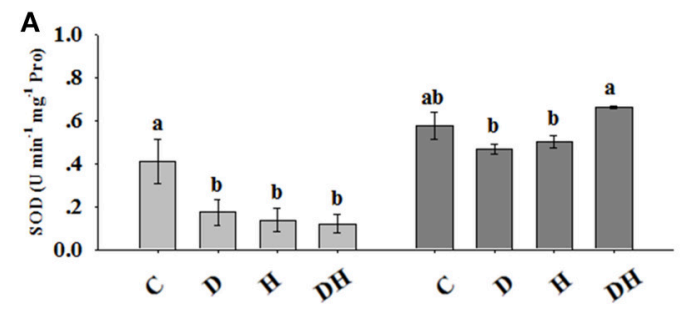

C

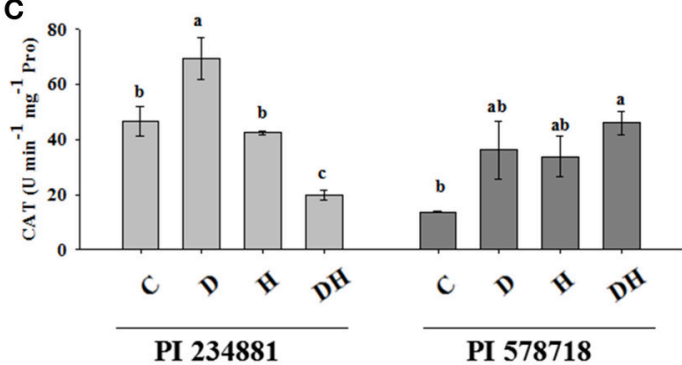

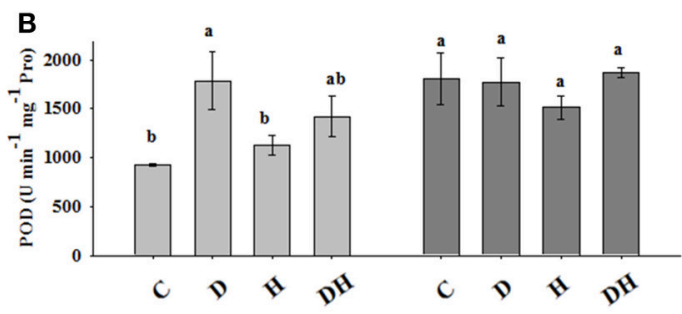

D

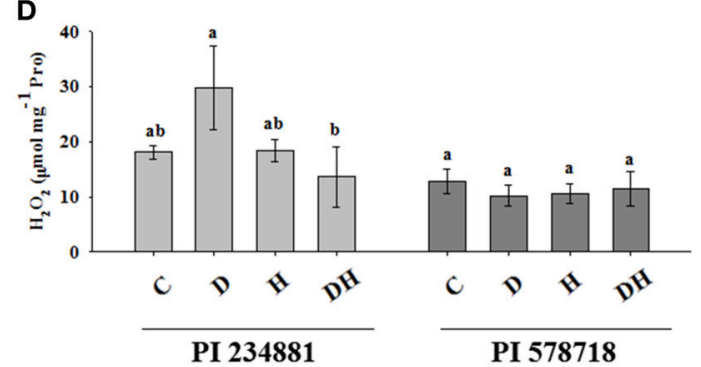

FIGURE 2 | The effects of stress treatments on SOD (A), POD (B), CAT (C) activities and $\mathrm{H}_{2} \mathrm{O}_{2}$ (D) content in 7 th leaves of PI 234881 and PI 578718 under control (C), drought (D), heat (H), combined stress (DH). Different letters indicate significant differences between treatments $(P<0.05)$ based on $L S D$ test.
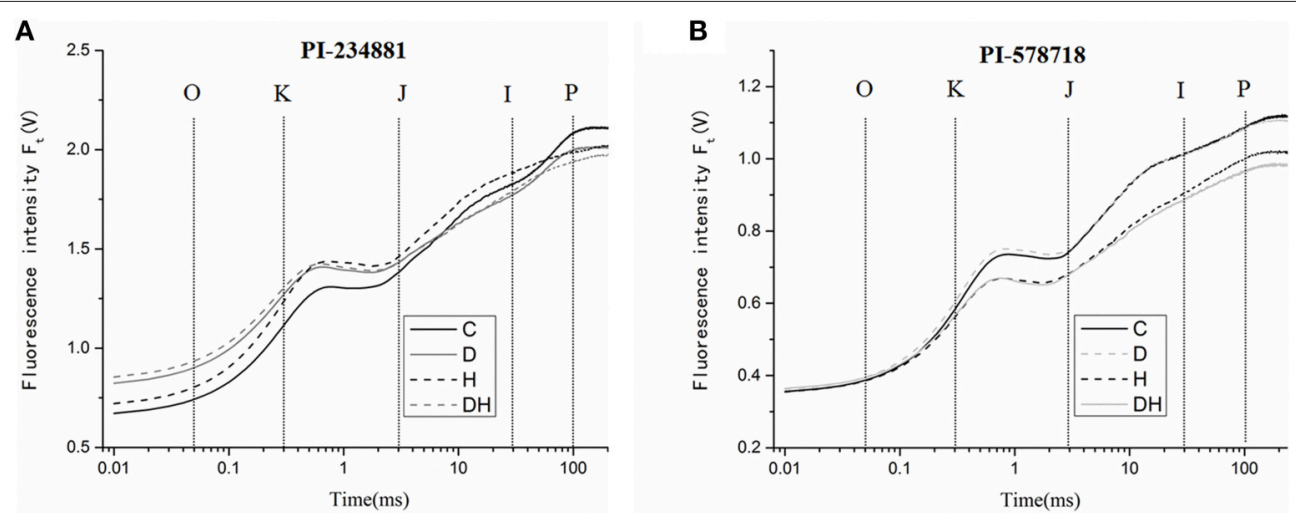

FIGURE 3 | The OJIP fluorescence transients in tall fescue leaves under control (C), drought (D), heat (H), combined stress (DH) in PI 234881 (A) and PI $\mathbf{5 7 8 7 1 8}$ (B) accessions. Tall fescue leaves were vacuum-infiltrated for $15 \mathrm{~min}$ in the dark.

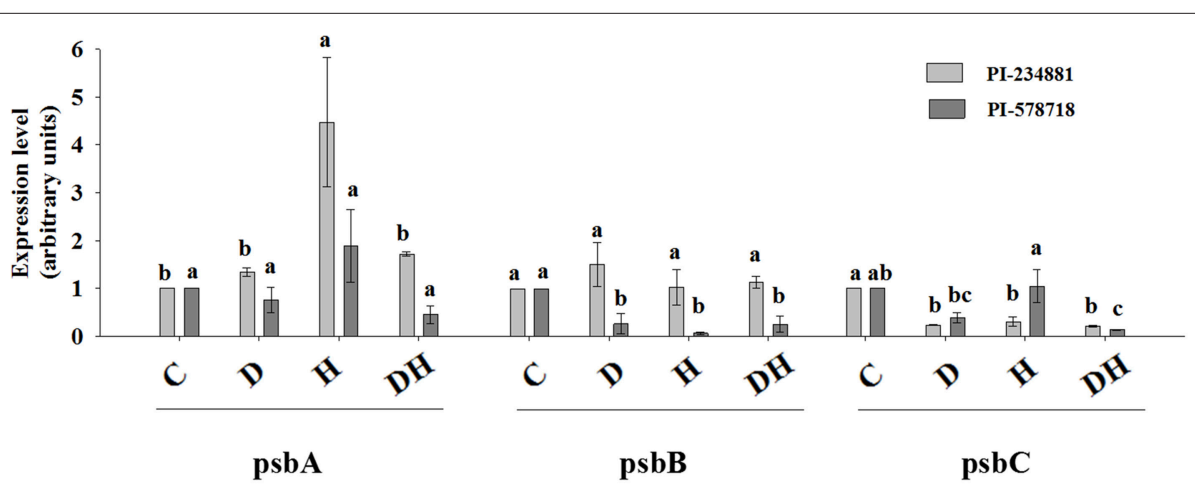

FIGURE 4 | Effect of drought (D), heat (H), combined stress (DH) on the gene transcription of tall fescue leaves. Tall fescue leaves were under water (Control), drought (D), heat (H), combined stress (DH) for 7th in the same incubator. Then tall fescue leaves were stored in liquid nitrogen for RT-PCR. Data are given as mean $\pm S D$ of three independent experiments. Different letters indicate statistical difference significance at $P<0.05$ among the treatments by Duncan's multiple range tests. 
TABLE 3 | Correlations among Chl, El, SOD, POD, CAT, $\varphi_{\mathrm{P} 0}, \gamma_{\mathrm{RC}}, \psi_{\mathrm{E} 0}, \mathrm{PI}_{\mathrm{ABS}}, \mathrm{RC} / \mathrm{ABS}$ in PI 234881 and PI 578718 tall fescue accessions under drought, heat, and the combined stress.

\begin{tabular}{|c|c|c|c|c|c|c|c|c|c|c|}
\hline & Chl & EI & SOD & POD & CAT & $\varphi_{\mathrm{PO}}$ & $\psi_{E O}$ & $\gamma_{\mathrm{RC}}$ & RC/ABS & $\mathrm{PI}_{\mathrm{ABS}}$ \\
\hline \multicolumn{11}{|c|}{ - - PI 234881-- } \\
\hline Chl & 1 & & & & & & & & & \\
\hline El & $-0.624^{\star \star}$ & 1 & & & & & & & & \\
\hline SOD & 0.480 & $-0.575^{\star}$ & 1 & & & & & & & \\
\hline POD & -0.217 & 0.451 & -0.370 & 1 & & & & & & \\
\hline CAT & 0.441 & -0.183 & 0.022 & 0.283 & 1 & & & & & \\
\hline$\varphi \mathrm{PO}$ & $0.704^{\star \star}$ & $-0.581^{\star}$ & 0.384 & $-0.500^{\star}$ & 0.347 & 1 & & & & \\
\hline$\psi_{E O}$ & 0.400 & -0.113 & 0.226 & -0.271 & 0.400 & 0.423 & 1 & & & \\
\hline$\gamma_{\mathrm{RC}}$ & $0.595^{\star}$ & -0.457 & 0.147 & -0.397 & 0.419 & $0.948^{\star \star}$ & 0.359 & 1 & & \\
\hline $\mathrm{RC} / \mathrm{ABS}$ & 0.251 & 0.028 & 0.042 & -0.159 & 0.459 & 0.254 & $0.957^{\star \star}$ & 0.265 & 1 & \\
\hline $\mathrm{PI}_{\mathrm{ABS}}$ & $0.638^{\star \star}$ & -0.460 & 0.346 & -0.456 & $0.519^{\star}$ & $0.846^{\star \star}$ & $0.789^{\star \star}$ & $0.816^{\star \star}$ & $0.704^{\star \star}$ & 1 \\
\hline \multicolumn{11}{|c|}{ - PI 578718- } \\
\hline Chl & 1 & & & & & & & & & \\
\hline El & $-0.568^{\star}$ & 1 & & & & & & & & \\
\hline SOD & 0.062 & 0.100 & 1 & & & & & & & \\
\hline POD & -0.217 & 0.321 & -0.107 & 1 & & & & & & \\
\hline CAT & 0.441 & -0.424 & 0.028 & 0.283 & 1 & & & & & \\
\hline$\varphi \mathrm{PO}$ & 0.464 & $-0.611^{*}$ & -0.262 & 0.239 & 0.400 & 1 & & & & \\
\hline$\psi_{\text {EO }}$ & 0.351 & 0.139 & 0.350 & -0.215 & -0.011 & 0.218 & 1 & & & \\
\hline$\gamma_{R C}$ & 0.037 & -0.163 & $-0.492^{\star}$ & $0.537^{\star}$ & 0.428 & $0.801^{\star \star}$ & 0.201 & 1 & & \\
\hline $\mathrm{RC} / \mathrm{ABS}$ & 0.132 & 0.346 & 0.242 & -0.154 & -0.059 & -0.018 & $0.903^{\star \star}$ & 0.226 & 1 & \\
\hline $\mathrm{PI}_{\mathrm{ABS}}$ & $0.536^{\star}$ & -0.362 & -0.082 & 0.160 & 0.343 & $0.877^{\star \star}$ & $0.623^{\star \star}$ & $0.770^{\star \star}$ & 0.430 & 1 \\
\hline
\end{tabular}

*Indicates statistical difference significance at $P<0.05$ among the treatments by Duncan's multiple range tests.

**Indicates statistical difference significance at $P<0.01$ among the treatments by Duncan's multiple range tests.

correlation was found between $\mathrm{Chl}$ and $\varphi_{\mathrm{P} 0}$ and $\mathrm{PI}_{\mathrm{ABS}}$, whereas $\mathrm{El}$ was negatively correlated with other trait variables. Particularly, CAT showed a positive correlation with $\mathrm{PI}_{\mathrm{ABS}}$ in $\mathrm{PI} 234881$. A significant negative correlation was found between SOD and $\gamma_{\mathrm{RC}}$ whereas POD was positively correlated with $\gamma_{\mathrm{RC}}$ in PI 578718.

\section{DISCUSSION}

In this study, we characterized the particular antioxidant metabolism and PSII photochemistry response pattern to drought, heat and a combination stress in two tall fescue accessions with different high-temperature tolerance. We found that high-temperature sensitive PI 234881 exhibited higher EL, $\mathrm{MDA}$, and $\mathrm{H}_{2} \mathrm{O}_{2}$ content, and the lower leaf $\mathrm{Chl}$ content compared to high-temperature tolerant PI 578718 under drought or heat stress or a combination stress. These results indicated that different abiotic stress conditions generated the fundamental differences between the acclimation responses to stress conditions in different plant sepecies, which provides adaptive flexibility to enhance survival potential.

Drought, heat, or a combination stress can generate the impact of varying degrees on RWC, Chl, MDA, and EL level in cool-season turfgrass (Huang et al., 1998). Shi et al. (2012) reported that different drought tolerant bermudagrass accessions had high natural variation of physiological traits and drought sensitive bermudagrass (Yukon) showed relative lower LWC, higher EL and more accumulation MDA than drought tolerant bermudagrass (Tifgreen). Here, RWC of the sensitive variety PI 234881 was more affected by drought alone, rather than by the combination, we hypothesis that the sensitive variety first stand a drought stress, and after a period of acclimation it then adatpted the enviroment. In addition, drought, heat, or the combined stresses generated significant declines in leaf $\mathrm{Chl}$ in both tall fescue genotypes. Heat-tolerant genotype PI 578718 maintained comparatively higher $\mathrm{Chl}$ content, and fewer decline compared to PI 234881. A sharp fall of Chl content would decrease the chloroplast biochemistry or Chl fluorescence. Droughtinduced stress weakened photosynthetic electron transfer and Chl contents as reported previously (Zuily-Fodil et al., 1990; Moran et al., 1994). The loss of Chl contents during stress measurements could also be related to photo-oxidation resulting from oxidative stress.

$\mathrm{El}$ and MDA were valuable indicators of the degree of cellular damages caused by environment stress (Hernández and Almansa, 2002). In the present study, a pronounced increase in EL for PI 234881 was observed when subjected drought and the combined stress. This suggests that an increase in membrane permeability or loss of membrane stability might lead to increased solute leakage. However, the EL in PI 578718 was $95.5 \%$ lower than in PI 234881, which suggested that the membrane permeability of heat-tolerant PI 578718 was less affected by drought stress, and had more enhanced protective mechanisms. These results are 
consistent with Bajji et al. (2001), who reported the mechanisms of higher membrane stability stress in durum wheat under water stress. In addition, consistent with Sekmen et al. (2014), our study indicated that there was less lipid peroxidation in PI 234881 genotype under combined stress. However, in PI 578718 there was more lipid peroxidation under combined stress than drought stress alone. This observation is consistent with previous studies (Jiang and Huang, 2000). The increase observed in leaf MDA contents of both genotypes after drought, heat and the combined stresses were in line with results from others (Price and Hendry, 1991; Zhang et al., 1995). In both tall fescue genotypes, the MDA content was the least affected parameter in the course of the entire experimental stress treatments. This indicated that the adaptabilities to drought and heat could be linked with minimum lipid peroxidation and high antioxidant enzymes antioxidant activities, particularly CAT.

Drought, heat, or the combined stress can also have an effect on varying degrees on ROS in cool-season turfgrass (Huang et al., 1998). Induction of antioxidant enzyme defense activities is highly correlated with increased environmental stress (Ashraf, 2009). Cellular SOD constitutes the first line of defense against ROS (Alscher et al., 2002), and it can catalyze the dismutation of superoxide radical $\left(\mathrm{O}_{2}^{-\bullet}\right)$ to oxygen and $\left(\mathrm{H}_{2} \mathrm{O}_{2}\right.$; Jaleel et al., 2009). The higher SOD activity in PI 578718 (heat tolerant) under the drought and heat stress could be a consequence of excess superoxide radical $\left(\mathrm{O}_{2}^{-\bullet}\right)$ generation. Superoxide radical has been regarded as a signal for antioxidant enzyme induction, and consequently, it might have resulted in greater induction of SOD (Almeselmani et al., 2006). This result indicated that the genotype PI 578718 had a high capacity to catalyze the dismutation of $\mathrm{O}_{2}^{-\bullet}$ to $\mathrm{H}_{2} \mathrm{O}_{2}$ and $\mathrm{O}_{2}$ under drought and heat stress. Although, there is precise report regarding the scavengers of oxygen or the hydroxyl radical ( $\cdot \mathrm{OH})$, SOD plays a functional role in their elimination by chemical reaction (Alvarez, 2000).

$\mathrm{POD}$ and CAT are among the major enzymes that scavenge $\mathrm{H}_{2} \mathrm{O}_{2}$ which is produced through the dismutation of $\mathrm{O}_{2}^{-}$in peroxisomes and chloroplasts. Drought stress increased the POX activity in soybean plants (Zhang et al., 2006). In the present study, the POD activity in heat-tolerant genotype PI 578718 under drought and heat stress was enhanced by a little $3.28 \%$ as compared to the control groups. Generally, PI 578718 showed considerably greater POD activity than PI 234881, which indicated that the former genotype has better scavenging ability and higher tolerance to drought and heat stress than the latter. These observations are consistent with the results of Almeselmani et al., (2006). In the present study, although CAT activity of heat-sensitive PI 234881 was enhanced under drought stress, its activity declined under the combined stress. This may be attributed to the increased $\mathrm{H}_{2} \mathrm{O}_{2}$ accumulation and lipid peroxidation which may have excited CAT and POD activities. These findings are almost the same consistent with what Sekmen et al. (2014) observed. As we have documented, the $\mathrm{H}_{2} \mathrm{O}_{2}$ content in drought-tolerant PI 234881 was higher than that in PI 578718. We hereby hypothesize that this is relevant because of CAT activity in PI 578718. The cooperation of POD and CAT in ROS scavenging is more complex, and might involve other peroxidases. The comparison of the heat-sensitive PI 234881 and heat-tolerant PI 578718 response pattern for SOD,
CAT, and POD activities to drought and heat stress indicated significant difference at different abiotic stress. Relatively heattolerant PI 578718 showed increased or decreased enzyme activities compared sensitive genotype PI 234881, which maybe is correlated with the temporal regulation of the constitutive isoenzymes as well as antioxidant genes.

Drought, heat, or the combined stress can exert an effect on varying degrees on PSII in chloroplast (Čajánek et al., 1998; Crafts-Brandner and Salvucci, 2002; Musil et al., 2009). The rise in chlorophyll fluorescence induction reveals a characteristic O-J-I-P polyphasic transient (Strasser et al., 2004). The performance index $\mathrm{PI}_{\text {total }}$ (performance index for energy conservation from exciton to the reduction of PSI end acceptors) is the most sensitive parameter of the JIP-test in evaluating plant photochemical activities under stressful condition. It incorporates several parameters that are evaluated from the fluorescence transient OJIP (Clark et al., 2000; Yusuf et al., 2010). From the JIP test, the maximum quantum yield for primary photochemistry $\left(\varphi_{\mathrm{P} 0} \equiv \mathrm{TR}_{0} / \mathrm{ABS}\right)$, the quantum yield of electron transport $\left(\varphi_{\mathrm{E} 0} \equiv \mathrm{ET}_{0} / \mathrm{ABS}\right)$ and the motion of a trapped exciton into the electron transport chain beyond $\mathrm{Q}_{\mathrm{A}}$ $\left(\psi_{0} \equiv \mathrm{ET}_{0} / \mathrm{TR}_{0}\right)$ could be estimated. The $\varphi_{\mathrm{P} 0}$ and $\varphi_{\mathrm{E} 0}$ values were markedly changed under drought and heat stress. However, the $\psi_{0}$ values were slightly altered under stress treatments. Our previous study showed that the behavior of PSII among six heattolerant accessions and five heat-sensitive accessions had various thermotolerance capacities in response to high-temperature stress (Chen et al., 2014). In this study, we also found the similar tendency that heat-tolerant PI 578718 obtained $12.82 \%$ increase of the relative variable fluorescence value but heat-sensitive PI 234881 receded by $4.76 \%$ the relative variable fluorescence value. Furthermore, Hagemeyer (2004) and Perales-Vela et al. (2007) reported that to protect the plant growth from extremely adverse environmental condition, excess excitation energy was transformed into thermal dissipation so as to maintain the energy balance between absorption and utilization. And the $\mathrm{PI}_{\text {total }}$ value under heat and the combined stress also confirmed this. However, the $\mathrm{PI}_{\text {total }}$ value under drought stress had a profound change. Therefore, we deduced that this discrepancy maybe on account of technical complexities and errors sample collection method, hence the results should be evaluated with maximum caution (Queval et al., 2008). For example, under heat stress, plants open their stomata to cool their leaves via transpiration. However, if heat stress is combined with drought, plants would not open the stomata and the leaf temperature would be higher (Rizhsky et al., 2002). Under single stress treatment $\varphi_{\mathrm{P} 0}, \psi_{0}, \varphi_{\mathrm{E} 0}$, and $\mathrm{PI}_{\mathrm{ABS}}$ values had no significant difference compared to the control group. Researchers reported that drought did not have a significant impact on the photosynthetic efficiency, and therefore photosynthesis was significantly compromised under heat stress. It was demonstrated that mild drought affected plant growth, but had subtle effects on the photosynthesis rate in Arabidopsis (Muller et al., 2011; Skirycz et al., 2011; Verelst et al., 2013).

CP43 ( $p s b B$ encoded protein) and CP47 ( $p s b C$ encoded protein; light-harvesting complex) are the intrinsic transmembrane proteins which are located in the reaction center of PSII.. In the present study, the transcription of CP43 and CP47 under drought, heat and the combined stress 
in PI 578718 and PI 234881 tall fescue genotypes decreased significantly. This resulted in the weakened RC, and thus confirmed that heat and the combined stress could accelerate photosynthesis. After CP47 was released from the reaction center (RC), light harvesting antenna would be uncoupled out of the $\mathrm{RC}$ and the damaged D1 protein would be cleavaged under detrimental environmental heat (Yoshioka et al., 2006). In the present study the expression of D1 protein is higher in PI 234881 than that in PI 578718 when under each stress group. The results indicated that the increase in $p s b A$ expression is benefitial to PSII $\mathrm{RC}$ by resisting drought and heat stress and improving the PSII recovery. As Takahashi et al. (2004) reported that the presence of highly reactive singlet oxygen in OEC is detrimental to the D1 protein, and heat stress enhances the susceptibility of this photosynthetic organs. Therefore, the novel expression of psbA is a supplement for the damaged D1 protein and is fairly vital for PSII. Of course, the gene expression of $p s b A, p s b B$, and $p s b C$ is not enough. Wang et al. (2015) have researched that Hsfs and their target genes in F. arundinacea and L. perenne also provied a foundation for future gene function studies to improve stress tolerance in grasses and other crops. Yang et al. (2015) also have reported that TIP41 combined with TUB and ACT was stably expressed in heat-stressed leaves and these suitable reference genes in tall fescue would allow for more accurate identification of stress-tolerance genes in this stress-tolerant species.

In the present study, differential adaptations in different plant species under different abiotic tolerance can have differential natural variation of physiological traits. Relatively heat-tolerant PI 578718 experienced greater increase or less decrease of enzyme activities compared to the heat-sensitive PI 234881. This may be correlated with the lower $\mathrm{H}_{2} \mathrm{O}_{2}$ content as well as antioxidant genes. Generally, drought, heat and the combined stresses triggered oxidative injury on diffirent levels in both tall

\section{REFERENCES}

Ali, B., Hasan, S., Hayat, S., Hayat, Q., Yadav, S., Fariduddin, Q., et al. (2008). A role for brassinosteroids in the amelioration of aluminium stress through antioxidant system in mung bean (Vigna radiata L. Wilczek). Environ. Exp. Bot. 62, 153-159. doi: 10.1016/j.envexpbot.2007.07.014

Almeselmani, M., Deshmukh, P., Sairam, R., Kushwaha, S., and Singh, T. (2006). Protective role of antioxidant enzymes under high temperature stress. Plant Sci. 171, 382-388. doi: 10.1016/j.plantsci.2006.04.009

Alscher, R. G., Erturk, N., and Heath, L. S. (2002). Role of superoxide dismutases (SODs) in controlling oxidative stress in plants. J. Exp. Bot. 53, 1331-1341. doi: 10.1093/jexbot/53.372.1331

Alvarez, M. E. (2000). "Salicylic acid in the machinery of hypersensitive cell death and disease resistance," in Programmed Cell Death in Higher Plants, eds E. Lam, H. Fukuda, and J. Greenberg (Springer Netherlands), 185-198.

Ashraf, M. (2009). Biotechnological approach of improving plant salt tolerance using antioxidants as markers. Biotechnol. Adv. 27, 84-93. doi: 10.1016/j.biotechadv.2008.09.003

Bajji, M., Lutts, S., and Kinet, J. M. (2001). Water deficit effects on solute contribution to osmotic adjustment as a function of leaf ageing in three durum wheat (Triticum durum Desf.) cultivars performing differently in arid conditions. Plant Sci. 160, 669-681. doi: 10.1016/S0168-9452(00)00443-X

Baxter, I., and Dilkes, B. P. (2012). Elemental profiles reflect plant adaptations to the environment. Science 336, 1661-1663. doi: 10.1126/science.12 19992 fescue genotypes, as showed by the reduction in antioxidant enzymes (e.g., SOD activity in 578718 and SOD and CAT activity in PI 234881), and increase in lipid peroxidation. Drought did not have significant impact on the photosynthetic efficiency i.e., photosynthesis was significantly compromised under heat and the combined stress. These results broadened our comprehension on various enzymatic antioxidant metabolism and PSII acclimation to drought, high-temperature and a combination of both stresses in cool-season turfgrass species. And the specific molecular mechanism underlying improved growth traits and stress tolerance is our further study.

\section{AUTHOR CONTRIBUTIONS}

$\mathrm{AB}$ carried out the experiments and wrote the manuscript. JF and $\mathrm{ZH}$ analyzed the data. GW assisted with doing the experiments. JF and TH. conceived and designed the experiments. TH and EA helped to draft the manuscript and revise the manuscript. All authors read and approved the final manuscript.

\section{ACKNOWLEDGMENTS}

This work was supported by funds from National Natural Science Foundation of China (No. 31272194, 31201653) and the China-Africa Center for Research and Education, CAS (No. SAJC201325).

\section{SUPPLEMENTARY MATERIAL}

The Supplementary Material for this article can be found online at: http://journal.frontiersin.org/article/10.3389/fpls.2016. 00453
Blokhina, O., Virolainen, E., and Fagerstedt, K. V. (2003). Antioxidants, oxidative damage and oxygen deprivation stress: a review. Ann. Bot. Lond. 91, 179-194. doi: $10.1093 / \mathrm{aob} / \mathrm{mcf} 118$

Bradford, M. M. (1976). A rapid and sensitive method for the quantitation of microgram quantities of protein utilizing the principle of proteindye binding. Anal. Biochem. 72, 248-254. doi: 10.1016/0003-2697(76) 90527-3

Čajánek, M., Štroch, M., Lachetová, I., Kalina, J., and Spunda, V. (1998). Characterization of the photosystem II inactivation of heat-stressed barley leaves as monitored by the various parameters of chlorophyll a fluorescence and delayed fluorescence. J. Photochem. Photobiol. 47, 39-45. doi: 10.1016/S10111344(98)00197-3

Chance, B., and Maehly, A. C. (1955). Methods in Enzymology, Vol. 2, eds S. P. Colowick and N. O. Kaplan (New York, NY: Academic Press), 764.

Chen, K., Sun, X., Amombo, E., Zhu, Q., Zhao, Z., Chen, L., et al. (2014). High correlation between thermotolerance and photosystem II activity in tall fescue. Photosyn. Res. 122, 305-314. doi: 10.1007/s11120-0140035-3

Clark, A. J., Landolt, W., Bucher, J., and Strasser, R. (2000). Beech (Fagus sylvatica) response to ozone exposure assessed with a chlorophyll a fluorescence performance index. Environ. Pollut. 109, 501-507. doi: 10.1016/S02697491(00)00053-1

Crafts-Brandner, S. J., and Salvucci, M. E. (2002). Sensitivity of photosynthesis in a C4 plant, maize, to heat stress. Plant Physiol. 129, 1773-1780. doi: $10.1104 /$ pp.002170 
Cushman, J. C., and Bohnert, H. J. (2000). Genomic approaches to plant stress tolerance. Curr. Opin. Plant Biol. 3, 117-124. doi: 10.1016/S13695266(99)00052-7

Demiral, T., Turkan, I., and Hediye Sekmen, A. (2011). Signalling strategies during drought and salinity, recent news. Adv. Bot. Res. 57, 294. doi: 10.1016/B978-012-387692-8.00008-4

Giannopolitis, C. N., and Ries, S. K. (1977). Superoxide dismutases I. Occurrence in higher plants. Plant Physiol. 59, 309-314. doi: 10.1104/pp.59.2.309

Hagemeyer, J. (2004). "Ecophysiology of plant growth under heavy metal stress," in Heavy Metal Stress in Plants, ed M. N. V. Prasad (Berlin; Heidelberg: Springer), 157-181.

Heath, R. L., and Packer, L. (1968). Photoperoxidation in isolated chloroplasts: I. Kinetics and stoichiometry of fatty acid peroxidation. Arch. Biochem. Biophys. 125, 189-198. doi: 10.1016/0003-9861(68)90654-1

Hernández, J. A., and Almansa, M. S. (2002). Short-term effects of salt stress on antioxidant systems and leaf water relations of pea leaves. Physiol. Plantarum 115, 251-257. doi: 10.1034/j.1399-3054.2002.1150211.x

Hideg, É., Barta, C., Kálai, T., Vass, I., Hideg, K., and Asada, K. (2002). Detection of singlet oxygen and superoxide with fluorescent sensors in leaves under stress by photoinhibition or UV radiation. Plant Cell Physiol. 43, 1154-1164. doi: $10.1093 / \mathrm{pcp} / \mathrm{pcf} 145$

Hiscox, J. T., and Israelstam, G. (1979). A method for the extraction of chlorophyll from leaf tissue without maceration. Can. J. Bot. 57, 1332-1334. doi: $10.1139 / \mathrm{b} 79-163$

Hoagland, D., and Arnon, D. (1950). The Water-Culture Method for Growing Plants without Soil. Berkeley, CA: California Experiment Station Circular 347, The College of Agriculture, University of California.

Hu, T., Liu, S., Amombo, E., and Fu, J. (2015). Stress memory induced rearrangements of HSP transcription, photosystem II photochemistry and metabolism of tall fescue (Festuca arundinacea Schreb.) in response to hightemperature stress. Front. Plant. Sci. 6:403. doi: 10.3389/fpls.2015.00403

Huang, B., Fry, J., and Wang, B. (1998). Water relations and canopy characteristics of tall fescue cultivars during and after drought stress. HortScience 33, 837-840.

Huang, B., and Gao, H. (1999). Physiological responses of diverse tall fescue cultivars to drought stress. HortScience 34, 897-901.

Jaleel, C. A., Riadh, K., Gopi, R., Manivannan, P., Inès, J., Al-Juburi, H. J., et al. (2009). Antioxidant defense responses: physiological plasticity in higher plants under abiotic constraints. Acta Physiol. Plant 31, 427-436. doi: 10.1007/s11738009-0275-6

Jena, S., and Choudhuri, M. A. (1981). Glycolate metabolism of three submerged aquatic angiosperms during aging. Aquat. Bot. 12, 345-354. doi: 10.1016/03043770(82)90026-2

Jiang, Y., and Huang, B. (2000). Effects of drought or heat stress alone and in combination on Kentucky bluegrass. Crop Sci. 40, 1358-1362. doi: $10.2135 /$ cropsci2000.4051358x

Kaigama, B. (1982). Effect of heat and water stress and their interactions on grain sorghum. Dissertation Abstracts International, Science and Engineering 43, 1962.

Karpinski, S., and Muhlenbock, P. (2007). Genetic, molecular and physiological mechanisms controlling cell death, defenses, and antioxidant network in response to abiotic and biotic stresses in plants. Comp. Biochem. Phys. A 146, S60. doi: 10.1016/j.cbpa.2007.01.054

Knight, H., and Knight, M. R. (2001). Abiotic stress signalling pathways: specificity and cross-talk. Trends Plant Sci. 6, 262-267. doi: 10.1016/S13601385(01)01946-X

Korres, N., Froud-Williams, R., and Moss, S. (2003). Chlorophyll fluorescence technique as a rapid diagnostic test of the effects of the photosynthetic inhibitor chlorotoluron on two winter wheat cultivars. Ann. Appl. Biol. 143, 53-56. doi: 10.1111/j.1744-7348.2003.tb00268.x

Lee, S., Ahsan, N., Lee, K., Kim, D., Lee, D., Kwak, S., et al. (2007). Simultaneous overexpression of both CuZn superoxide dismutase and ascorbate peroxidase in transgenic tall fescue plants confers increased tolerance to a wide range of abiotic stresses. J. Plant Physiol. 164, 1626-1638. doi: 10.1016/j.jplph.2007.01.003

Mohanty, P., Allakhverdiev, S. I., and Murata, N. (2007). Application of low temperatures during photoinhibition allows characterization of individual steps in photodamage and the repair of photosystem II. Photosyn. Res. 94, 217-224. doi: 10.1007/s11120-007-9184-y
Moran, J. F., Becana, M., Iturbe-Ormaetxe, I., Frechilla, S., Klucas, R. V., and Aparicio-Tejo, P. (1994). Drought induces oxidative stress in pea plants. Planta 194, 346-352. doi: 10.1007/BF00197534

Muller, B., Pantin, F., Génard, M., Turc, O., Freixes, S., Piques, M., et al. (2011). Water deficits uncouple growth from photosynthesis, increase $\mathrm{C}$ content, and modify the relationships between $\mathrm{C}$ and growth in sink organs. J. Exp. Bot. 62, 1715-1729. doi: 10.1093/jxb/erq438

Murata, N., Takahashi, S., Nishiyama, Y., and Allakhverdiev, S. I. (2007). Photoinhibition of photosystem II under environmental stress. Biochim. Biophys. Acta 1767, 414-421. doi: 10.1016/j.bbabio.2006.11.019

Musil, C., Van Heerden, P., Cilliers, C., and Schmiedel, U. (2009). Mild experimental climate warming induces metabolic impairment and massive mortalities in southern African quartz field succulents. Environ. Exp. Bot. 66, 79-87. doi: 10.1016/j.envexpbot.2008.11.008

Perales-Vela, H. V., González-Moreno, S., Montes-Horcasitas, C., and Cañizares-Villanueva, R. O. (2007). Growth, photosynthetic and respiratory responses to sub-lethal copper concentrations in Scenedesmus incrassatulus (Chlorophyceae). Chemosphere 67, 2274-2281. doi: 10.1016/j.chemosphere.2006.11.036

Pfannschmidt, T. (2003). Chloroplast redox signals: how photosynthesis controls its own genes. Trends Plant Sci. 8, 33-41. doi: 10.1016/S1360-1385(02)00005-5

Pinheiro, C., Passarinho, J. A., and Ricardo, C. P. (2004). Effect of drought and rewatering on the metabolism of Lupinus albus organs. J. Plant Physiol. 161, 1203-1210. doi: 10.1016/j.jplph.2004.01.016

Pospišil, P. (2012). Molecular mechanisms of production and scavenging of reactive oxygen species by photosystem II. Biochim. Biophys. Acta 1817, 218-231. doi: 10.1016/j.bbabio.2011.05.017

Price, A., and Hendry, G. (1991). Iron-catalysed oxygen radical formation and its possible contribution to drought damage in nine native grasses and three cereals. Plant Cell Environ. 14, 477-484. doi: 10.1111/j.13653040.1991.tb01517.x

Queval, G., Hager, J., Gakière, B., and Noctor, G. (2008). Why are literature data for $\mathrm{H} 2 \mathrm{O} 2$ contents so variable? A discussion of potential difficulties in the quantitative assay of leaf extracts. J. Exp. Bot. 59, 135-146. doi: $10.1093 / \mathrm{jxb} / \mathrm{erm} 193$

Rizhsky, L., Liang, H., and Mittler, R. (2002). The combined effect of drought stress and heat shock on gene expression in tobacco. Plant Physiol. 130, 1143-1151. doi: $10.1104 /$ pp.006858

Scandalios, J. G., Guan, L., and Polidoros, A. N. (1997). Catalases in plants: gene structure, properties, regulation, and expression. Cold Spring Harb. Monogr. Ser. 34, 343-406.

Sekmen, A. H., Ozgur, R., Uzilday, B., and Turkan, I. (2014). Reactive oxygen species scavenging capacities of cotton (Gossypium hirsutum) cultivars under combined drought and heat induced oxidative stress. Environ. Exp. Bot. 99, 141-149. doi: 10.1016/j.envexpbot.2013.11.010

Shah, N. (1992). Responses of wheat to combined high temperature and drought or osmotic stresses during maturation. Diss. Abstr. Int. 52, 3984-3989.

Shi, H., Wang, Y., Cheng, Z., Ye, T., and Chan, Z. (2012). Analysis of natural variation in bermudagrass (Cynodon dactylon) reveals physiological responses underlying drought tolerance. PLOS ONE 7:e53422 doi: 10.1371/journal.pone.0053422

Shinozaki, K., and Yamaguchi-Shinozaki, K. (2000). Molecular responses to dehydration and low temperature: differences and cross-talk between two stress signaling pathways. Curr. Opin. Plant Biol. 3, 217-223. doi: 10.1016/S13695266(00)00067-4

Skirycz, A., Vandenbroucke, K., Clauw, P., Maleux, K., De Meyer, B., Dhondt, S., et al. (2011). Survival and growth of Arabidopsis plants given limited water are not equal. Nat. Biotechnol. 29, 212-214. doi: 10.1038/ nbt. 1800

Stirbet, A. (2011). On the relation between the Kautsky effect (chlorophyll a fluorescence induction) and photosystem II: basics and applications of the OJIP fluorescence transient. J. Photochem. Photobiol. B 104, 236-257. doi: 10.1016/j.jphotobiol.2010.12.010

Strasser, R. J., Tsimilli-Michael, M., and Srivastava, A. (2004). "Analysis of the chlorophyll a fluorescence transient," in Chlorophyll a Fluorescence, eds G. C. Papageorgiou and Govindjee (Springer Netherlands), 321-362.

Takahashi, S., Nakamura, T., Sakamizu, M., van Woesik, R., and Yamasaki, H. (2004). Repair machinery of symbiotic photosynthesis as the primary target 
of heat stress for reef-building corals. Plant Cell Physiol. 45, 251-255. doi: $10.1093 / \mathrm{pcp} / \mathrm{pch} 028$

Umena, Y., Kawakami, K., Shen, J.-R., and Kamiya, N. (2011). Crystal structure of oxygen-evolving photosystem II at a resolution of 1.9 Å. Nature 473, 55-60. doi: 10.1038 /nature09913

Verelst, W., Bertolini, E., De Bodt, S., Vandepoele, K., Demeulenaere, M., Pè, M. E., et al. (2013). Molecular and physiological analysis of growth-limiting drought stress in Brachypodium distachyon leaves. Mol. Plant 6, 311-322. doi: $10.1093 / \mathrm{mp} / \mathrm{sss} 098$

Wang, W. X., Vinocur, B., Shoseyov, O., and Altman, A. (2001). Biotechnology of plant osmotic stress tolerance physiological and molecular considerations. Acta Hortic. 560, 285-292. doi: 10.17660/ActaHortic.2001.560.54

Wang, Y., Dai, Y., Tao, X., Wang, J.-Z., Cheng, H.-Y., Yang, H., et al. (2015). Heat shock factor genes of tall fescue and perennial ryegrass in response to temperature stress by RNA-seq analysis. Front. Plant Sci. 6:226. doi: 10.3389/fpls.2015.01226

Wang, Z.-Y., Hopkins, A., Lawrence, R., Bell, J., and Scott, M. (2004). "Field evaluation and risk assessment of transgenic tall fescue (Festuca arundinacea) plants," in Molecular Breeding of Forage and Turf, eds A. Hopkins, Z.-Y. Wang, R. Mian, M. Sledge, and R. E. Barker (Springer Netherlands), 367-379.

Yang, Z., Chen, Y., Hu, B., Tan, Z., and Huang, B. (2015). Identification and validation of reference genes for quantification of target gene expression with quantitative real-time PCR for tall fescue under four abiotic stresses. PLoS ONE 10:e0119569. doi: 10.1371/journal.pone.0119569

Yordanov, I., Tsonev, T., Merakchiiska-Nikolova, M., Georgieva, K., and Goltsev, V. (1997). Gas exchange and chlorophyll fluorescence during water and high temperature stresses and recovery. Probable protective effect of carbamide cytokinin 4-PU30. Photosynthetica (Czech Republic) 33, 423-431.

Yoshioka, M., Uchida, S., Mori, H., Komayama, K., Ohira, S., Morita, N., et al. (2006). Quality control of photosystem II cleavage of reaction center D1 protein in spinach thylakoids by FtsH protease under moderate heat stress. J. Biol. Chem. 281, 21660-21669. doi: 10.1074/jbc.M602896200
Yusuf, M. A., Kumar, D., Rajwanshi, R., Strasser, R. J., Tsimilli-Michael, M., and Sarin, N. B. (2010). Overexpression of $\gamma$-tocopherol methyl transferase gene in transgenic Brassica juncea plants alleviates abiotic stress: physiological and chlorophyll a fluorescence measurements. Biochim. Biophys. Acta 1797, 1428-1438. doi: 10.1016/j.bbabio.2010.02.002

Zabalza, A., Gálvez, L., Marino, D., Royuela, M., Arrese-Igor, C., and González, E. M. (2008). The application of ascorbate or its immediate precursor, galactono1, 4-lactone, does not affect the response of nitrogen-fixing pea nodules to water stress. J. Plant Physiol. 165, 805-812. doi: 10.1016/j.jplph.2007.08.005

Zhang, J., Jia, W., Yang, J., and Ismail, A. M. (2006). Role of ABA in integrating plant responses to drought and salt stresses. Field Crop Res. 97, 111-119. doi: 10.1016/j.fcr.2005.08.018

Zhang, J. X., Cui, S. P., Li, J. M., Wei, J. K., and Kirkham, M. B. (1995). Protoplasmic factors, antioxidant responses, and chilling resistance in maize. Plant Physiol. Biochem. 33, 567-575.

Zhu, J. (2001). Cell signaling under salt, water and cold stresses. Curr. Opin. Plant Biol. 4, 401-406.

Zhu, J. (2002). Salt and drought stress signal transduction in plants. Annu. Rev. Plant Biol. 53, 247. doi: 10.1146/annurev.arplant.53.091401.143329

Zuily-Fodil, Y., Vazquez-Tello, A., and Vieira Da Silva, J. (1990). Effect of water deficit on cell permeability and on chloroplast integrity. Bull. Soc. Bot. Fr. Actual. Bot. 137, 115-123. doi: 10.1080/01811789.1990.10826992

Conflict of Interest Statement: The authors declare that the research was conducted in the absence of any commercial or financial relationships that could be construed as a potential conflict of interest.

Copyright (c) 2016 Bi, Fan, Hu, Wang, Amombo, Fu and Hu. This is an open-access article distributed under the terms of the Creative Commons Attribution License (CC $B Y)$. The use, distribution or reproduction in other forums is permitted, provided the original author(s) or licensor are credited and that the original publication in this journal is cited, in accordance with accepted academic practice. No use, distribution or reproduction is permitted which does not comply with these terms. 